\title{
Revision of the rhynchonellid and atrypid brachiopods from the lower Pragian (Devonian) of Southeast Alaska (Heceta Island)
}

\author{
VALERYI V. BARANOV \& ROBERT B. BLODGETT
}

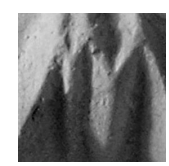

\begin{abstract}
A new collection of brachiopods made in 2003 from lower Pragian beds of the northeastern part of Heceta Island of Southeast Alaska allows us the opportunity to reevaluate some of the rhynchonellid and atrypid brachiopods that were previously described by Kirk \& Amsden (1952) and Savage (1981) from the same locality. We here describe the following taxa: Kirkirhynchus gen. nov. with Ancillotoechia reesidei Kirk \& Amsden, 1952 designated type species, Savagerhynchus hecetaensis gen. et sp. nov., Dubovikovia cf. kuzmini (Cherkesova, 1968) and Rugosatrypa flexibilis (Cherkesova in T. Modzalevskaya \& Cherkesova, 1994). The occurrence of the two last species allows correlation of the lower Pragian beds of Heceta Island with Uryumskay, Tolbatskay and basal part of Daksanskay layers of Taimyr, Russia and the Soda Creek Limestone of west-central Alaska. Close faunal ties are clearly evidenced by Pragian brachiopod faunas of Southeast Alaska, southwest Alaska, Northeast Asia, and Taimyr. - Key words: rhynchonellids, atrypids, brachiopods, lower Pragian, Southeast Alaska, Heceta Island.
\end{abstract}

BARANOV, V.V. \& BLODGETT, R.B. 2015. Revision of the rhynchonellid and atrypid brachiopods from the lower Pragian (Devonian) of Southeast Alaska (Heceta Island). Bulletin of Geosciences 90(1), 21-32 (9 figures, 4 tables). Czech Geological Survey, Prague. ISSN 1214-1119. Manuscript received December 9, 2013; accepted in revised form May 5, 2014; published online November 25, 2014; issued January 26, 2015.

Valeryi V. Baranov, Institute of Diamond and Precious Metals Geology, Yakutsk Research Center, Siberian Division, Russian Academy of Sciences, pr. Lenina 39, Yakutsk, 677980, Sakha Republic (Yakutia), Russia; baranowvalera@yandex.ru・Robert B. Blodgett, Consulting Geologist, 2821 Kingfisher Drive, Anchorage, Alaska 99502, U.S.A.; robertbblodgett@gmail.com

The present paper describes and revises the taxonomic assignment of rhynchonellid and atrypid brachiopods from a new collection made by R.B. Blodgett at the now "classic" USGS locality 2689-SD on the northeast part of Heceta Island, Southeast Alaska (Fig. 1). This important locality was originally thought to be late Silurian in age (Kirk \& Amsden, 1952), but subsequently revised to an early Pragian age (Savage 1977, 1981; Blodgett et al. 2010; Baranov \& Blodgett 2011, 2012, and herein). The material used in this study was collected by R.B. Blodgett (his locality 03RB16) and A.E.H. Pedder on June 30, 2003 from free-weathering fossils in shaly limestones in the northeast corner of Heceta Island, Southeast Alaska (Fig. 1). The locality was visited by them in a small boat, as there are no roads that allow access. The GPS coordinates for this locality are latitude $55^{\circ} 48.265^{\prime} \mathrm{N}$, longitude $133^{\circ} 20.979^{\prime} \mathrm{W}$, and is situated in the NE1/4 of the NW1/4 of the SE1/4 of the NE1/4 of section 18, T. $70 \mathrm{~S}$, R. 79 E, Craig D-5 1:63,360 scale quadrangle (Map edition 1996). This locality is the same as USGS locality 2689-SD [= field locality 47-AH-R120(F) of G. Donald Eberlein which he and his USGS field party collected in 1947 during regional geologic mapping]. The geographic coordinates given for this locality in Savage (1977) is latitude $55^{\circ} 48^{\prime} \mathrm{N}$ and longitude $133^{\circ} 21^{\prime} \mathrm{W}$. This exposure of limestone, shaly limestone and shale was included within the red-bed clastic unit named the Karheen Formation by Eberlein \& Churkin (1970), and is surrounded along the adjoining shoreline to the north and south by typical exposures consisting of red colored sandstones of the Karheen Formation (see Savage 1981, fig. 2 for an even more detailed map location). The locality was also shown as locality 16 in Eberlein et al. (1983). Subsequently, Blodgett et al. (2010) suggested placing this exposure rather in the overlying Devonian age Wadleigh Limestone, and having it fault-bounded to the north and south by structurally discordant beds of the latest Silurian age Karheen Formation.

\section{Previous studies}

The fossil fauna from USGS locality 2689-SD includes brachiopods, rugose corals, trilobites, tentaculitids, and 


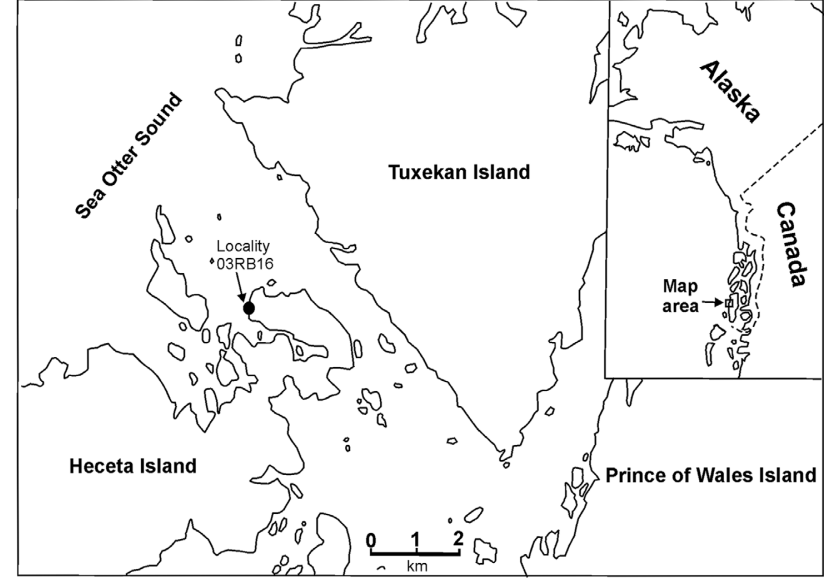

Figure 1. Map of the Southeast Alaska showing the location of collection $03 R B 16$ on Heceta Island.

conodonts, with only detailed taxonomic descriptions or illustrations being provided for on the brachiopods (Kirk \& Amsden 1952, Savage 1981, and herein), rugose corals (Merriam in Oliver et al. 1975), and conodonts (Savage 1977). Kirk \& Amsden (1952) in their monographic study "Upper Silurian brachiopods of Southeastern Alaska" described brachiopods from seven U.S. Geological Survey collections, one of which (USGS locality 2689-SD) (see Fig. 1 for location) was subsequently shown to be early Pragian (Middle Early Devonian) in age by Savage (1977, 1981). The six other collections are correctly assigned a late Silurian age. From USGS locality 2689-SD they described two species of rhynchonellids - Camarotoechia reesidei Kirk \& Amsden, 1952 and Camarotoechia sp., and one atrypid species - Atrypa cf. Atrypa reticularis (Linnaeus).

C.W. Merriam in Oliver et al. (1975, p. 37, pl. 22, figs 11,12 ) cited and illustrated the presence of a rugose coral he identified as Phaulactus sp. cf. P. cyathophylloides Ryder from USGS locality 2689-SD (= USGS loc. M1294 of that paper). Another species of Phaulactis, $P$. sp. cf. $P$. angusta (Londsdale) was noted by him as being present on the nearby Ham Island, which is located southeast of the eastern end of Heceta Island. The two collections served as the basis of his proposed Phaulactis Zone that he assumed occupied the uppermost strata of the upper Silurian succession near Heceta Island.

Later, Savage (1977, 1981) described conodonts and brachiopods, respectively, from USGS locality 2689-SD. Among the conodonts (Savage 1977) reported the zonal subspecies-index of the lower Pragian Eognathodus sulcatus sulcatus Philip and the following species: Ozarkodina eberleini sp. nov., Pandorinellina exigua philipi Klapper and Pelekysgnathus klamathensis Savage. Subsequently, Savage (1981) in his study of the brachiopods described a species complex consisting of Schizophoria cf. S. fragilis Kozlowski, Mesodouvillina (Protocymostrophia) cf. M. (P.) costatula (Barrande), Eoschuchertella sp., Gypidula aff. G. pelagica (Barrande), Ancillotoechia reesidei (Kirk \& Amsden), Linguopugnoides carens (Barrande), Monadotoechia? sp. nov., Atrypa reticularis (Linnaeus), Protathyris? sp., Nucleospira hecetensis Kirk \& Amsden, Reticulariopsis sp., Cyrtina sp., and Howellella amsdeni sp. nov., which in his opinion represented a typical cosmopolitan Pragian Old Word Realm fauna. Savage in his 1981 paper assigned Kirk \& Amsden's Camarotoechia reesidei to the genus Ancillotoechia Havlíček, 1959, their Camarotoechia sp. to the genus Linguopugnoides Havlíček, 1961, and their Atrypa cf. Atrypa reticularis to Atrypa reticularis.

Savage had visited the locality in 1975 together with G.D. Eberlein and M. Churkin, Jr. to collect conodont samples, resulting in the publication by Savage et al. (1977) on the conodont fauna. Subsequently, N.M. Savage and several student assistants visited the general vicinity in 1979 and spent two days collecting brachiopod and new conodont samples from a measured section they made here (the brachiopods being the subject of the paper published by Savage in 1981). Eberlein et al. (1983) provided faunal lists for a number of fossil localities in the Craig Quadrangle and noted for USGS locality 2689-SD the presence of brachiopods, the coral Phaulactus, the tentaculitid genus Nowakia, and conodonts. Blodgett et al. (2010) suggested these carbonate exposures represent a down-faulted block of the overlying Devonian age Wadleigh Limestone.

Blodgett et al. (2010) noted that many of the brachiopods recorded by Savage (1981) from this locality showed striking similarities with undescribed brachiopods from the Soda Creek Limestone of west-central Alaska (then thought to be early Emsian in age, but now known to also be of early Pragian age).

\section{Repository}

The brachiopods described in this paper are deposited in the Geology Museum of the Institute of Diamond and Precious Metals Geology (GM IDPMG), Yakutsk, Sakha Republic (Yakutia), Yakutsk, Russia, collection N 201.

\section{Systematic palaeontology}

Order Rhynchonellida Kuhn, 1949

Superfamily Rhynchotrematoidea Schuchert, 1913

Family Trigonirhynchiidae Schmidt, 1965

Subfamily Trigonirhynchiinae Schmidt, 1965

\section{Genus Kirkirhynchus gen. nov.}

Type species. - Camarotoechia reesidei Kirk \& Amsden, 1952; lower Pragian (Middle Early Devonian) of Heceta Island, Southeast Alaska. 


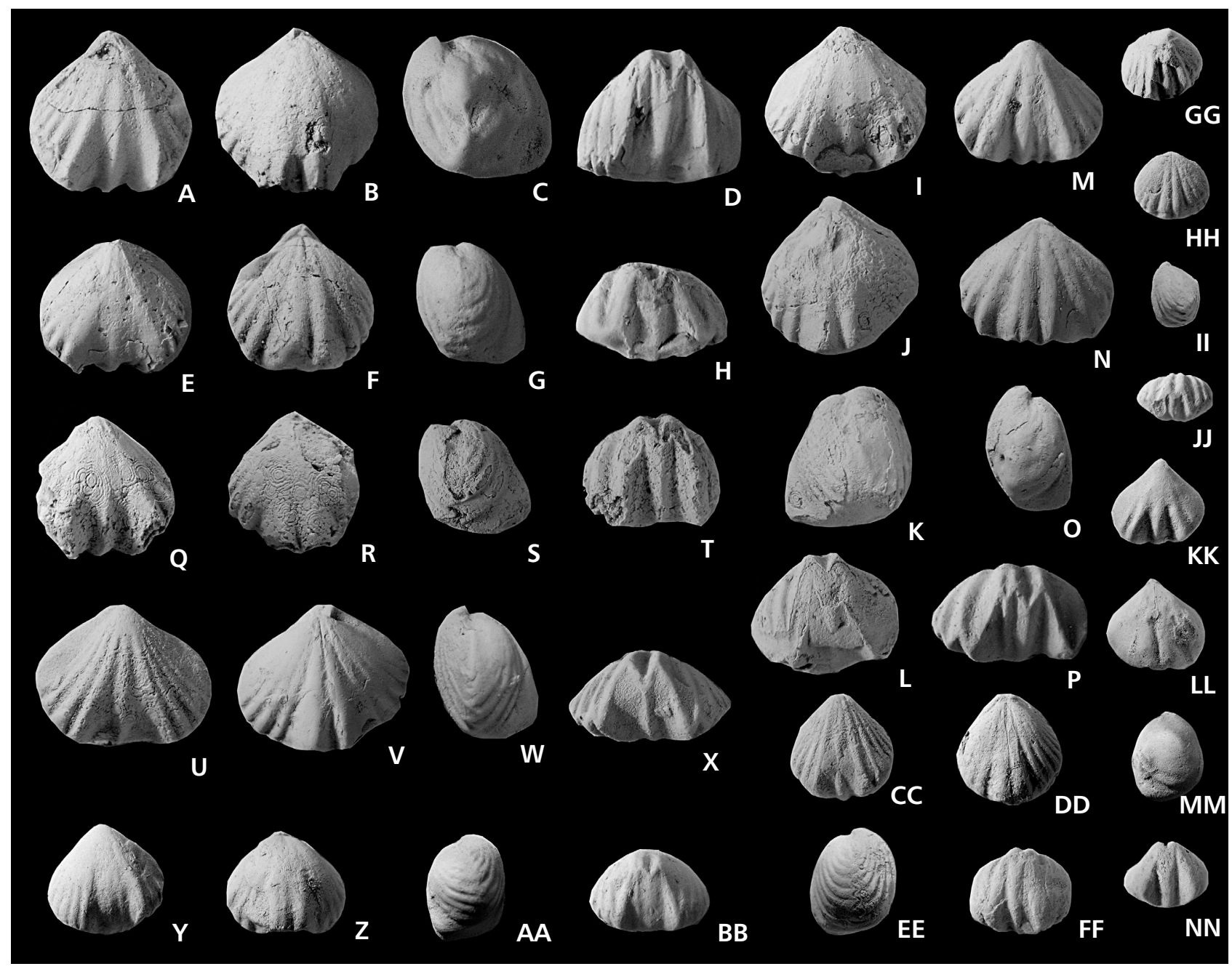

Figure 2. Kirkirhynchus reesidei (Kirk \& Amsden, 1952). A-NN - ventral, dorsal, lateral and anterior views of hypotypes, A-D - GM IDPMG 1/201, $\times 2$; E-H - GM IDPMG 2/201, × 2; I-L - GM IDPMG 3/201, ×2; M-P - GM IDPMG 4/201, ×2; Q-T - GM IDPMG 5/201, ×2; U-X - GM IDPMG 6/201, × 2; Y-BB - GM IDPMG 7/201, × 2; CC-FF - GM IDPMG 8/201, × 2; GG-JJ - GM IDPMG 9/201, × 2; KK-NN - GM IDPMG 9/201, × 2; Lower Devonian, lower Pragian, Heceta Island, Southeast Alaska.

Etymology. - In honor of Edwin Kirk (1884-1955), USGS paleontologist, who made many pioneering contributions to Alaskan paleontology (including papers on brachiopods, gastropods, bivalves, and crinoids) and stratigraphy.

Diagnosis. - Shell small, oval-subpentagonal with intraplicate anterior commissure and costae arising from the beak or within $2.5 \mathrm{~mm}$ from it; dorsibiconvex; sulcus deep with a central costa and with one to two costellae on each side; beak low, erect, pierced by small foramen; fold high with two flat costae which can bifurcate anteriorly; four to five costae located on the flanks; dental plates thin and short; lateral cavities filled with callus in mature shells; teeth massive; septalium short; dental sockets deep; inner hinge plate completely covered by a septalium which is concave dorsally and has an U-shaped outline in mature shells; crura raduliform, sharply curved ventrally.
Comparison. - Kirkirhynchus gen. nov. differs from the majority of genera belonging to the Trigonirhynchiinae in the character of the external ornament and in the presence of a U-shaped inner hinge plate completely covered by a septalium in mature shells (see Fig. 3). Kirkirhynchus differs from Ancillotoechia Havlíček, 1959 and Myrmirhynx Havlíček, 1982 in the presence of an apical callus in the ventral valve, a central costa in the sinus and by one to two costellae on each flank, a bifurcating flat costa on the fold, and an U-shaped inner hinge plate completely covered by a septalium in mature shells; from Trigonirhynchia Cooper, 1942, Agarhynchia Havlíček, 1982, Cupularostrum Sartenaer, 1961, Hercotrema Jin, 1989, and Oxypleurorhynchia Plodowski, 1973 it differs in having a central costa on the sinus and by the presence of one to two costellae on each flank, by the bifurcation of costae on the fold, and in having an U-shaped inner hinge plate completely covered by the septalium in mature shells. 

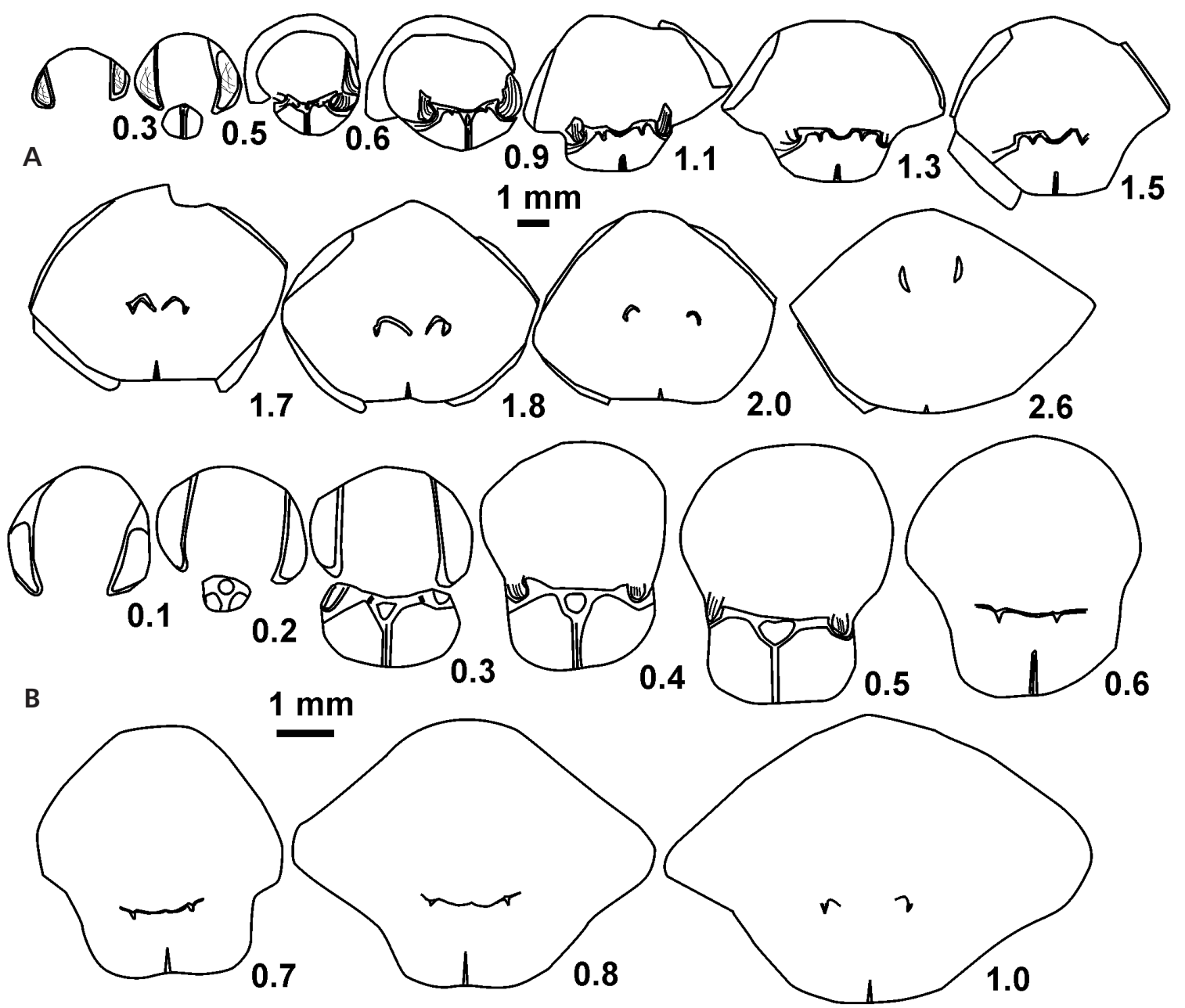

Figure 3. Selected transverse serial sections illustrating the internal structures in Kirkirhynchus reesidei (Kirk \& Amsden, 1952). A - hypotype, GM IDPMG 11/201, B - hypotype, GM IDPMG 12/201, Lower Devonian, lower Pragian, Heceta Island, Southeast Alaska. Scale bar represents 1 mm; length of sectioned specimens, $10.3 \mathrm{~mm}$ and $7.7 \mathrm{~mm}$.

Species assigned. - Only the type species is known.

Kirkirhynchus reesidei (Kirk \& Amsden, 1952) Figures 2A-NN, 3

1952 Camarotoechia reesidei; Kirk \& Amsden, p. 57, pl. 8, figs $1-7$.

1981 Ancillotoechia reesidei. - Savage, p. 364, pl. 3, figs 1-18.

Diagnosis. - Because of monotypy, see that of genus.

Material examined. - Fifty-eight conjoined valves from locality 03RB16, Heceta Island, Southeast Alaska.

Types. - Hypotypes, GM IDPMG, 1/201, Fig. 2A-D; GM IDPMG 2/201, Fig. 2E-H; GM IDPMG 3/201, Fig. 2I-L; GM IDPMG 4/201, Fig. 2M-P; GM IDPMG 5/201,
Fig. 2Q-T; GM IDPMG 6/201, Fig. 2U-X; GM IDPMG 7/201, Fig. 2Y-BB; GM IDPMG 8/201, Fig. 2CC-FF; GM IDPMG 9/201, Fig. 2GG-JJ; GM IDPMG 10/201, Fig. 2KK-NN; GM IDPMG 11/201, Fig. 3A; and GM IDPMG 12/201, Fig. 3B.

Measurements (in mm). -

\begin{tabular}{lrrrrr} 
Specimen & \multicolumn{1}{c}{$\mathrm{L}$} & $\mathrm{W}$ & $\mathrm{T}$ & $\mathrm{L} / \mathrm{W}$ & $\mathrm{L} / \mathrm{T}$ \\
$1 / 201$ & 12.0 & 11.8 & 11.9 & 1.01 & 1.0 \\
$2 / 201$ & 9.9 & 11.0 & 7.2 & 0.9 & 1.4 \\
$3 / 201$ & 9.9 & 10.5 & 8.3 & 0.94 & 1.2 \\
$4 / 201$ & 9.3 & 10.8 & 6.4 & 0.86 & 1.5 \\
$5 / 201$ & 10.0 & 9.2 & 7.2 & 1.09 & 1.39 \\
$6 / 201$ & 9.6 & 11.4 & 9.3 & 0.84 & 1.03 \\
$7 / 201$ & 7.4 & 7.0 & 5.5 & 1.06 & 1.35 \\
$8 / 201$ & 7.0 & 7.7 & 5.3 & 0.9 & 1.32 \\
$9 / 201$ & 5.0 & 6.0 & 4.0 & 0.83 & 1.25 \\
$10 / 201$ & 5.1 & 5.2 & 5.4 & 0.98 & 0.94
\end{tabular}



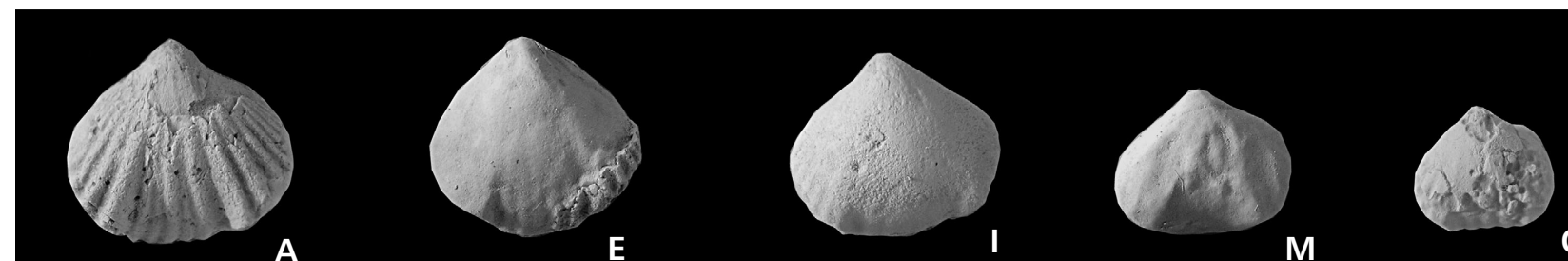

A

E

M
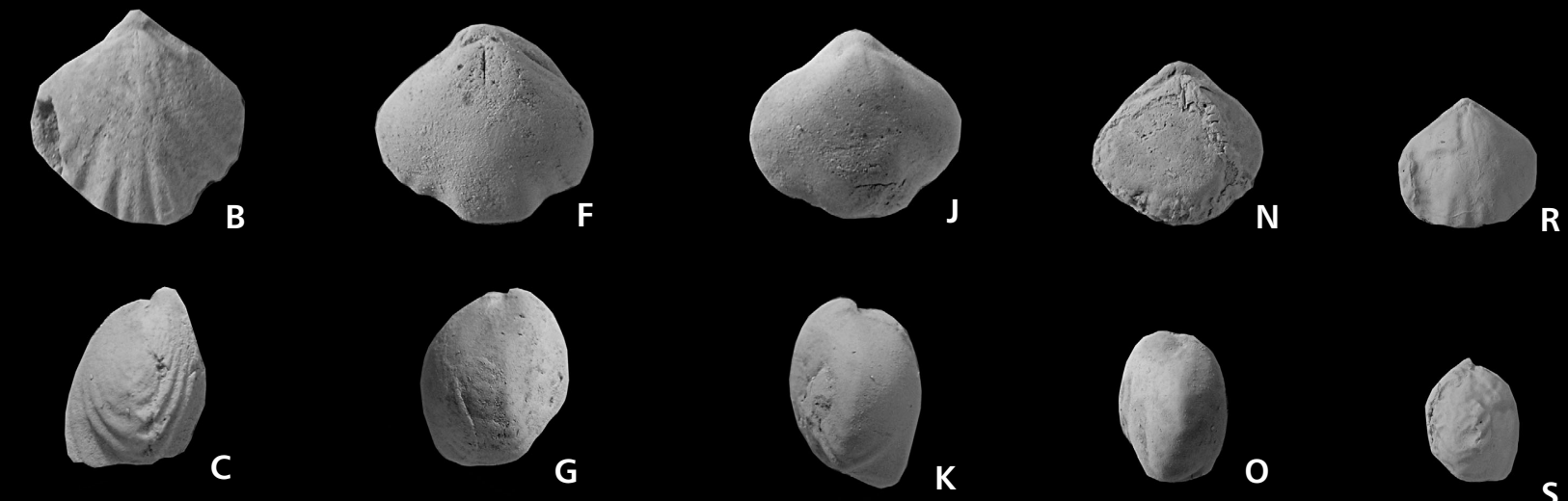

S

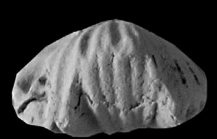

D
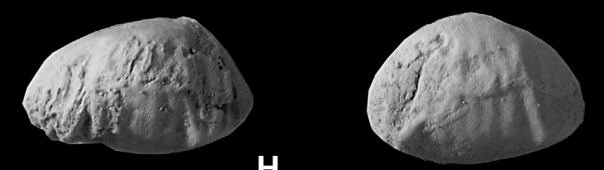

H

L
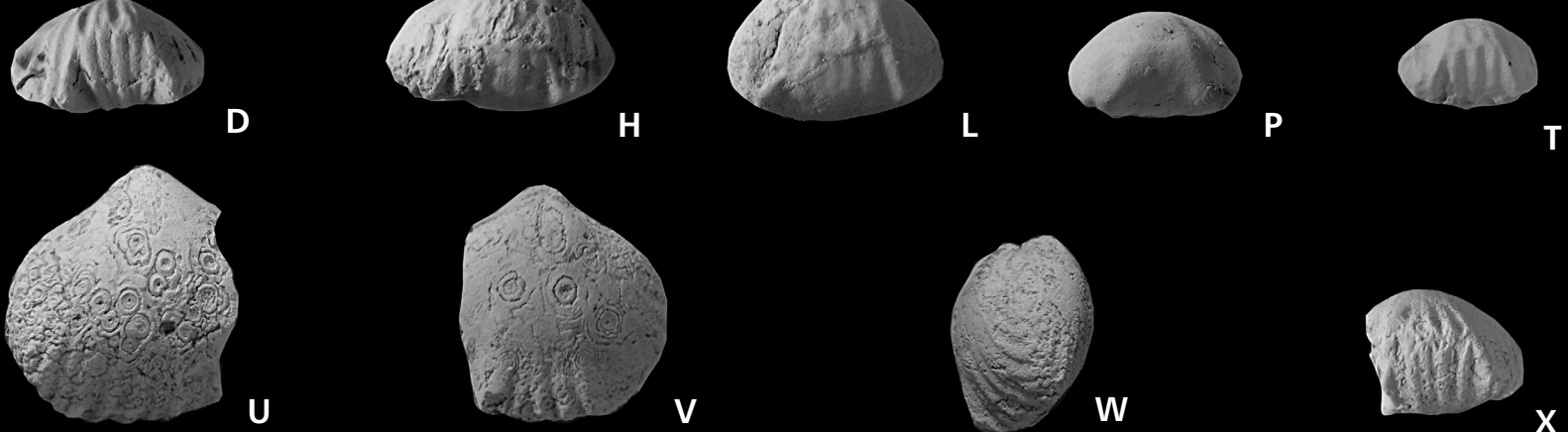

P
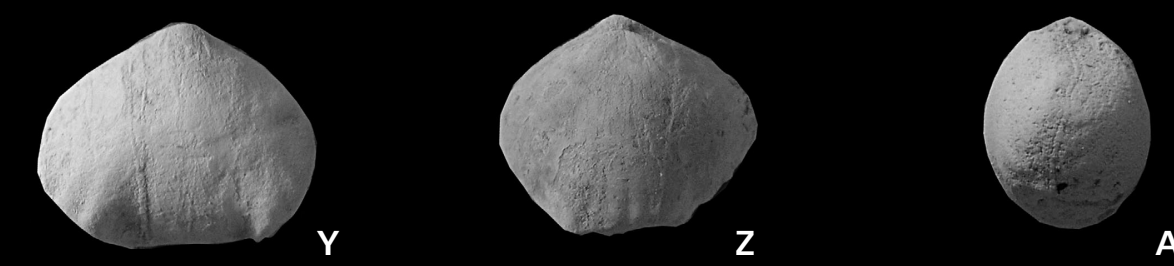

AA

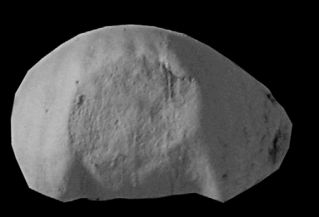

Figure 4. Savagerhynchus hecetaensis gen. et sp. nov. $-A-D$ - ventral, dorsal, lateral and anterior views of holotype, GM IDPMG 21/201, $\times 2$. -E-BB - ventral, dorsal, lateral and anterior views of paratypes: E-H - GM IDPMG 22/201, × 2; I-L - GM IDPMG 23/201, × 2; M-P - GM IDPMG 24/201, ×2; Q-T - GM IDPMG 25/201, × 2; U-X - GM IDPMG 26/201, × 2; Y-BB - GM IDPMG 27/201, × 2. Lower Devonian, lower Pragian, Heceta Island, Southeast Alaska.

\section{Genus Savagerhynchus gen. nov.}

Type species. - Savagerhynchus hecetaensis gen. et sp. nov.; lower Pragian (Middle Early Devonian) of Heceta Island, Southeast Alaska.

Etymology. - In honor of Norman M. Savage, Department of Geological Sciences, University of Oregon, Eugene,
Oregon, USA, who made many contributions to the study of Paleozoic brachiopods and conodonts of Southeast Alaska.

Diagnosis. - Shell small, transversely oval-subpentagonal in outline, dorsibiconvex with dorsal valve more strongly arched than the ventral valve; the greatest width and thickness are located at mid-length; anterior margin 
truncated, anterior commissure denticulate. Costae rounded, arising in the posterior half of the valves, intercalating on the sinus and bifurcating on the fold. Ventral valve gently convex in lateral profile; flanks flat; beak incurved. Sulcus and fold are developed in the anterior half of valves; fold low and wide, weakly delineated from the lateral flanks; sulcus shallow and wide with a flat bottom; tongue trapezoidal. Foramen small, permesothyrid. Three to five costae located on the sulcus; four to six costae are present on the fold; and five to six pairs are present laterally on the flanks. Dental plates thin and short; apical lateral cavities filled by callus. Septalium in the apical part open, anteriorly it is covered by the inner hinge plate, and can be traced up to the point where the crura branch. Dorsal medium septum thin, extending more than one seventh of the valve length; crura raduliform.

Comparison. - Savagerhynchus differs from Linguopugnoides Havlíček, 1961 in having an inner hinge plate covered by a septalium; from Astua Havlíček, 1992 it differs in being smaller and in having costae that are developed in the anterior half of valves, flattened with short longitudinal grooves on lateral margins and a septalium covered by an inner hinge plate; from Lissopleura Whitfield, 1896 it differs in having a smaller number of stronger, unflattened costae, which are bifurcated on the fold and intercalated on the sinus, and in the presence of a thin, short median septum.

\section{Savagerhynchus hecetaensis sp. nov.}

Figures 4A-BB, 5

1952 Camarotoechia sp.; Kirk \& Amsden, p. 58, pl. 10, figs $2-4$.

1981 Linguopugnoides carens (Barrande, 1879). - Savage, p. 365, pl. 3, figs 19-36.

1981 Monadotoechia? sp. nov. - Savage, p. 365, pl. 3, figs 37-46.

Diagnosis. - Because of monotypy, see that of genus.

Etymology. - After Heceta Island, Southeast Alaska.

Material examined. - Fifty-eight conjoined valves from locality 03RB16, northeast part of Heceta Island, Southeast Alaska.

Types. - Holotype, GM IDPMG, 21/201, Fig. 4A-D; paratypes, GM IDPMG 22/201, Fig. 4E-H; GM IDPMG 23/201, Fig. 4I-L; GM IDPMG 24/201, Fig. 4M-P; GM IDPMG 25/201, Fig. 4Q-T; GM IDPMG 26/201, Fig. 4U-X; GM IDPMG 27/201, Fig. 4Y-BB; GM IDPMG 28/201, Fig. 5.
Measurements (in mm). -

$\begin{array}{lrrrrr}\text { Specimen } & \text { L } & \text { W } & \text { T } & \text { L/W } & \text { L/T } \\ 21 / 201 & 12.0 & 11.2 & 7.0 & 0.9 & 1.71 \\ 22 / 201 & 10.6 & 11.3 & 7.8 & 0.94 & 1.36 \\ 23 / 201 & 10.2 & 11.4 & 8.0 & 0.89 & 1.28 \\ 24 / 201 & 8.9 & 9.1 & 5.8 & 0.98 & 1.53 \\ 25 / 201 & 6.8 & 7.0 & 4.8 & 0.97 & 1.42 \\ 26 / 201 & 12.2 & ? & 8.8 & ? & 1.39 \\ 27 / 201 & 11.5 & 14.1 & 9.6 & 0.82 & 1.2\end{array}$

Superfamily Uncinuloidea Rzhonsnitskaya, 1956

Family Innaechiidae Baranov, 1980

Genus Dubovikovia Baranov

(in Baranov \& Schischkina, 1995)

Type species. - Hebetoechia settedabanica Rzhonsnitskaya in Alekseeva 1967; Settedaban Formation, Lochkovian, Sette-Daban Range, Siberia.

\section{Dubovikovia cf. kuzmini (Cherkesova, 1968)}

Figures 6A-D, 7

1968 Hebetoechia kuzmini; Cherkesova, p. 16, pl. 1, figs 1-4, 10-12.

1981 Lanceomyonia kuzmini (Cherkesova). - Modzalevskaya, p. 177, pl. 1, figs 7-9.

Material examined. - One conjoined valve from locality 83RB16, Heceta Island, Southeast Alaska. This specimen has been serially sectioned (Fig.7).

Figured specimen. - GM IDPMG, 30/201, Figs 6A-D, 7.

Description. - Shell small, transversely subpentagonal in outline, dorsibiconvex with dorsal valve more strongly arched than ventral valve. The greatest width and thickness are located at midlength. Anterior margin truncated. Anterior commissure denticulate, with short marginal spines. Costae appear in anterior half of the valves, and are flattened with longitudinal grooves on lateral and anterior shell margins, and crossed by closely spaced concentric lamellae. Ventral valve moderately convex in longitudinal profile, flanks flat. Ventral beak incurved. Dorsal sulcus and ventral fold are developed in the anterior half of valves; sulcus shallow and wide with a flat bottom; tongue rectangular. Sulcus marked by four costae and four costal pairs laterally. Delthyrium closed by narrow deltidial plates; foramen small, oval, permesothyrid; dental plates thin and short. Dorsal valve strongly convex in lateral profile. Fold ornamented by five costae and five costal pairs laterally. Flanks steep to vertical. 


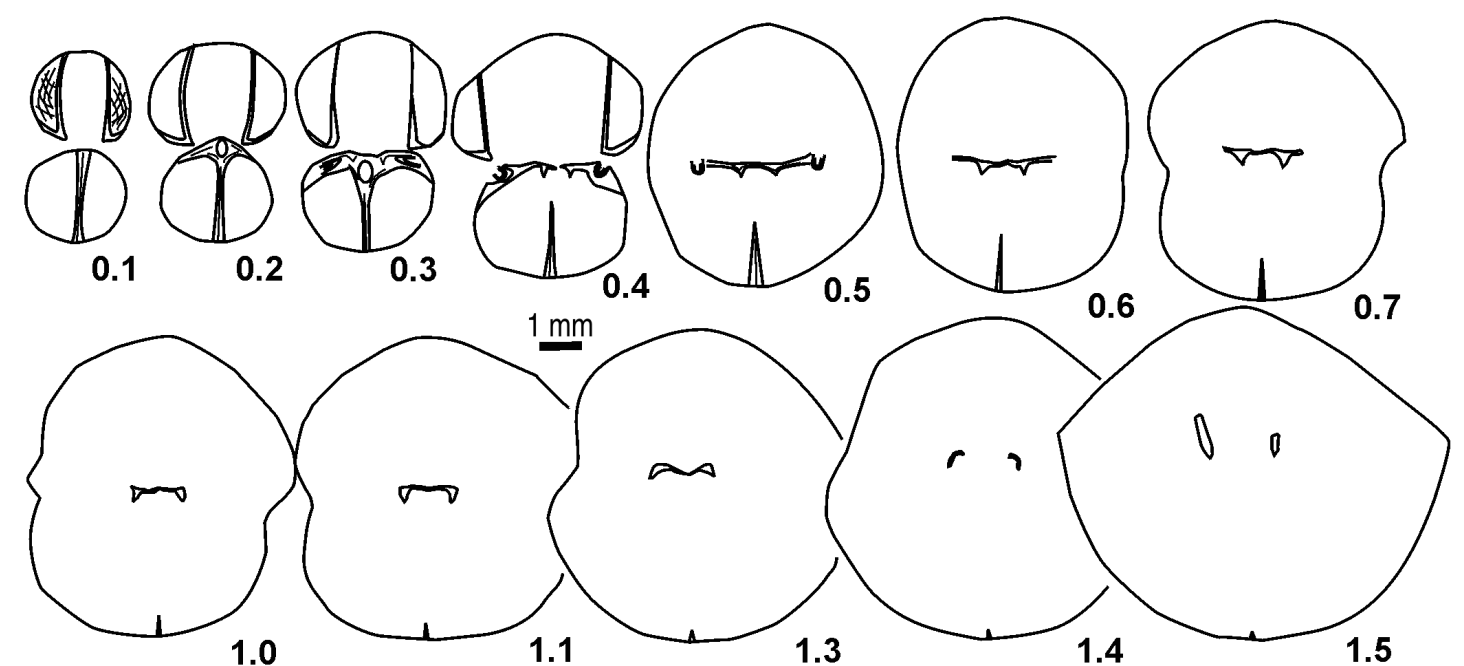

Figure 5. Selected transverse serial sections illustrating the internal structures in Savagerhynchus hecetaensis gen. et sp. nov., GM IDPMG 28/201, Lower Devonian, lower Pragian, Heceta Island, Southeast Alaska. Scale bar represents $1 \mathrm{~mm}$; numbers represent distance from initial section through specimen; original length of section specimen $10.0 \mathrm{~mm}$.

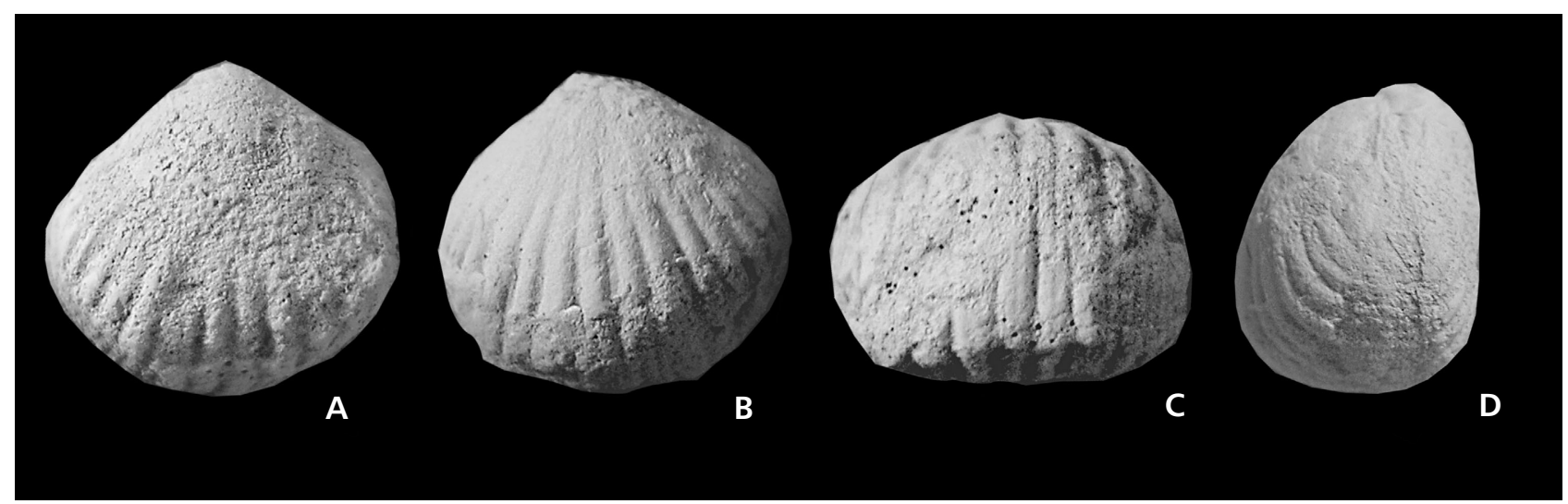

Figure 6. Dubovikovia cf. kuzmini (Cherkesova, 1968). A-D - ventral, dorsal, anterior and lateral views, GM IDPMG 30/201, ×3.5; Lower Devonian, lower Pragian, Heceta Island, Southeast Alaska.

The inner ends of outer hinge plates are curved dorsally. Septalium small. The dorsal median septum thin, extending more than one fifth of valve length (Figs 6, 7).

Measurements (in $\mathrm{mm}$ ). -

$\begin{array}{lcccrr}\text { Specimen } & \mathrm{L} & \mathrm{W} & \mathrm{T} & \mathrm{L} / \mathrm{W} & \mathrm{L} / \mathrm{T} \\ 30 / 201 & 12.0 & 12.6 & 9.2 & 0.9 & 1.3\end{array}$

Remarks. - On the basis of both external and internal features the Alaskan Dubovikovia cf. kuzmini does not differ from representatives of this species described by Cherkesova (1968) from the Uryumskay layers of Central Taimyr. Alaskan Dubovikovia cf. kuzmini are characterized by a larger shell size. The paucity of material (only one specimen) does not allow us to assign it with complete confidence to this species. Dubovikovia cf. kuzmini differs from mature shells of "Lancemyo- nia" varia Cherkesova (1968) by being smaller and in having its costae appears in the anterior part of the valves.

Occurrence. - Middle Lower Devonian, lower Pragian, Heceta Island, Southeast Alaska and possibly Uryumskay layers, Central Taimyr, East Siberia.

Order Atrypida Rzhonsnitskaya, 1960

Subfamily Atrypoidea Schuchert \& LeVene, 1929

Family Atrypidae Gill, 1871

\section{Genus Rugosatrypa Rzhonsnitskaya, 1975 (= Anulatrypa Havlíček, 1987)}

Type species. - Rugosatrypa tschernyschewi gen. et sp. nov.; Emsian, Southern Siberia. 


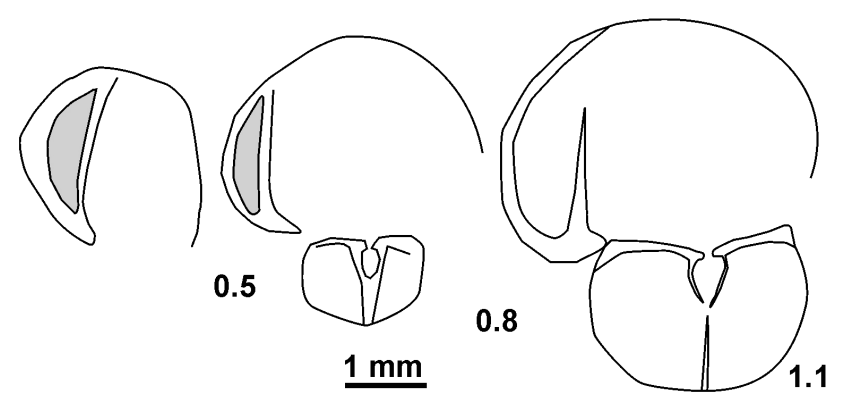

Figure 7. Selected transverse serial sections illustrating the internal structures in Dubovikovia cf. kuzmini (Cherkesova, 1968), GM IDPMG 30/201, Lower Devonian, lower Pragian, Heceta Island, Southeast Alaska. Scale bar represents $1 \mathrm{~mm}$; numbers represent distance from initial section through specimen; length of sectioned specimen $10.0 \mathrm{~mm}$.

\section{Rugosatrypa flexibilis Cherkesova, 1994 (in T. Modzalevskaya \& Cherkesova 1994) \\ Figure 8A-L, 9}

1952 Atrypa cf. Atrypa reticularis (Linnaeus). - Kirk \& Amsden, p. 63, pl. 8, figs 8-17.

1981 Atrypa reticularis (Linnaeus). - Savage, p. 85, pl. 2, figs 18-23.

1994 Anulatrypa flexibilis; Cherkesova (in T. Modzalevskaya \& Cherkesova), p. 57, pl. 5, figs 8-11.

Description. - Shell medium-sized, oval in outline, strongly dorsibiconvex, egg-like, carinate in the apical region, with the greatest width and thickness at mid-length. Cardinal extremities rounded. Ventral valve weakly convex at mid-length. Lateral slopes flattened. Anterior commissure sulcate. Sinus moderately developed. Dorsal valve more convex than ventral valve. Maximum thickness located in the posterior half of valve. Lateral slopes abrupt. Fold absent. Surface ornamented by thin bifurcating and intercalating ribs which are crossed by concentric growth lamellae. Number of ribs on the ventral valve at $5 \mathrm{~mm}$ from the beak are 11-13. Apical part of shells thick. Dental plates absent. Dental nucleus present. Teeth smooth. Inner socket ridge high. Dental sockets deep. Crural base subhorizontal.

Discussion. - Representatives of Rugosatrypa flexibilis are clearly very closely related to Anulatrypa nieczlaviensis tenuicostata Cherkesova in Cherkesova \& T. Modzalevskaya (1994, p. 56, pl. 5, figs 3-5) and differ only in having a more convex egg-like shell.

Material examined. - Seven conjoined shells from the locality 83RB16, Heceta Island, Southeast Alaska.

Types. - Hypotypes GM IDPMG, 31/201, Fig. 6A-D; GM IDPMG 32/201, Fig. 8E-H; and GM IDPMG 33/201, Fig. 8I-L.
Measurements (in mm). -

$\begin{array}{lccccr}\text { Specimen } & \text { L } & \text { W } & \text { T } & \text { L/W } & \text { L/T } \\ 31 / 201 & 22.3 & 22.6 & 13.8 & 0.98 & 1.61 \\ 32 / 201 & 17.3 & 18.9 & 12.1 & 0.92 & 1.43 \\ 33 / 201 & 18.8 & 17.4 & 11.3 & 1.08 & 1.7\end{array}$

Occurrence. - Middle Lower Devonian, lower Pragian, Heceta Island, Southeast Alaska and lower part of Daksanskay layers, Central Taimyr, East Siberia.

\section{Taxonomic summary}

This study describes the rhynchonellid and atrypid brachiopods from this locality based on collections made by R.B. Blodgett in 2003 (his locality 03RB16). An internal hinge plate was found in both rhynchonellid genera, a feature present in Ancillotoechia but absent in Linguopugnoides (Havlíček 1959, 1961) and also in the diagnoses of these genera (Savage 1996, 2002a, 2002b). An inner hinge plate is found in various phylogenetic lines of the rhynchonellids (family Glossinotoechiidae Havlíček, 1992; subfamily Trigonirhynchiinae Schmidt, 1965; and the genus Pseudouncinulus Rzhonsnitskaya, 1968) and occurs at various taxonomic ranks. We have included Ancillotoechia reesidei Kirk \& Amsden in our new genus Kirkirhynchus, which differs from Ancillotoechia both in external and internal structure (see "Description" below). The Linguopugnoides carens (Barrande, 1879) which was described by Savage (1981) we have included in Savagerhynchus hecetaensis gen. et sp. nov. Its differences from the genus Linguopugnoides are mentioned below. In the synonymy of Savagerhynchus hecetaensis we have also included Monadotoechia? sp. nov. (Savage 1981) as its external and internal structures do not differ from juvenile shells of Savagerhynchus hecetaensis. Moreover, we here document the occurrence of Dubovikovia cf. kuzmini, similar or identical to D. kuzmini described by Cherkesova (1968) from the Lochkovian (or lower Pragian as recently reinterpreted by Baranov \& Blodgett 2011, 2012) beds of Taimyr. Kirk \& Amsden (1952) from USGS locality 2689-SD described an atrypid - Atrypa cf. Atrypa reticularis (Linnaeus). The age of the brachiopod fauna from this locality was dated by them as late Silurian. However, Savage (1977) described an early Pragian conodont fauna from the same locality, and he subsequently described (Savage, 1981) the atrypid Atrypa reticularis (Linnaeus) among the brachiopods from the same locality. It is important to note that the holotype of this species was described from the lower Ludlow of Gotland, thus accounting for a large time interval between these two reported occurrences. Kozlowski (1929), and later Nikiforova (1954), described the variety Atrypa reticularis (Linné) var. nieczlawiensis from Lochkovian beds 


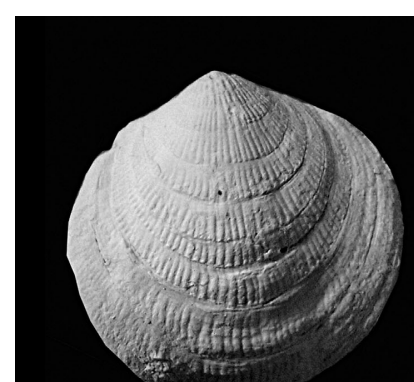

A

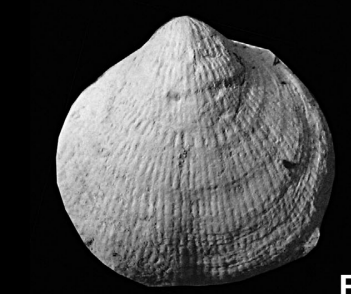

E
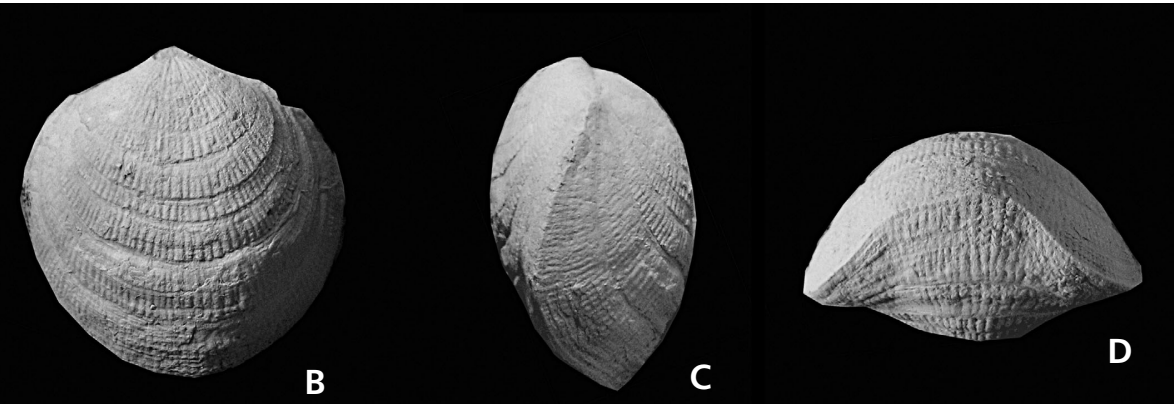

C

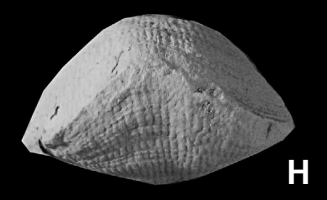

Figure 8. Rugosatrypa flexibilis (Cherkesova in T. Modzalevskaya \& Cherkesova, 1994), ventral, dorsal, lateral and anterior views. • A-D - GM IDPMG 40/201, ×1.5; E-H - GM IDPMG 41/201, ×1.5; I-L - GM IDPMG 42/201, ×1.5; Lower Devonian, lower Pragian, Heceta Island, Southeast Alaska.

(Borshchov Horizon) of Podolia, which differs from other varieties in having four costae grouped together in the apical part of the ventral valve. Rzhonsnitskaya (1975) and Cooper \& Racheboueuf (1985) included Atrypa nieczlawiensis as a member of the genus Rugosatrypa Rzhonsnitskaya, 1975, but Havlíček (1987) included Atrypa nieczlawiensis in the genus Anulatrypa Havlíček, 1987. In his opinion it differs from Rugosatrypa also in the presence of frills. However, the absence of frills in Rugosatrypa may be explained by insufficient preservation in the shells of the type species, though the presence of sharp concentric growth lamellae already assumes the presence of frills. This view is also confirmed by the occurrence of frills in Rugosatrypa moldavantzewi pjasinensis (Cherkesova in T. Modzalevskaya \& Cherkesova, 1994). Therefore, we believe that Anulatrypa is a junior synonym of the genus Rugosatrypa.

\section{Age and correlation}

The Pragian age limestone, shaly limestone, and shale sequence exposed on the northeast side of Heceta Island, which includes locality 03RB16 (= USGS locality 2689-SD), is associated with the late Silurian to Early Devonian age Karheen Formation as named and mapped by Eberlein \& Churkin (1970). Savage (1977) firmly established an early Pragian age for this exposure on the basis of conodonts and included it as part of the Karheen Formation. Savage (1981) described in detail the Pragian age brachiopods from this same exposure. Blodgett et al. (2010) expressed doubt that this exposure belongs to the Karheen Formation (which is characteristically a red-bed clastic unit composed of conglomerate, sandstones, and minor siltstone), and indicated that the exposure was probably a fault-bounded block of the overlying Devonian age Wadleigh Limestone. Blodgett et al. (2010) suggested restricting the classic red bed strata of the Karheen Formation to the upper Silurian based on available paleontological identifications provided from these beds in Buddington \& Chapin [1929, their Sgs (sandstone and graywacke) unit]. The Lower Devonian limestone exposure is structurally discordant, with strikingly differing bedding attitudes, with surrounding exposures of the Karheen Formation on the northeastern tip of Heceta Island (see map of Savage 1981, fig. 2). Locality 03RB16 shares several brachiopod species 


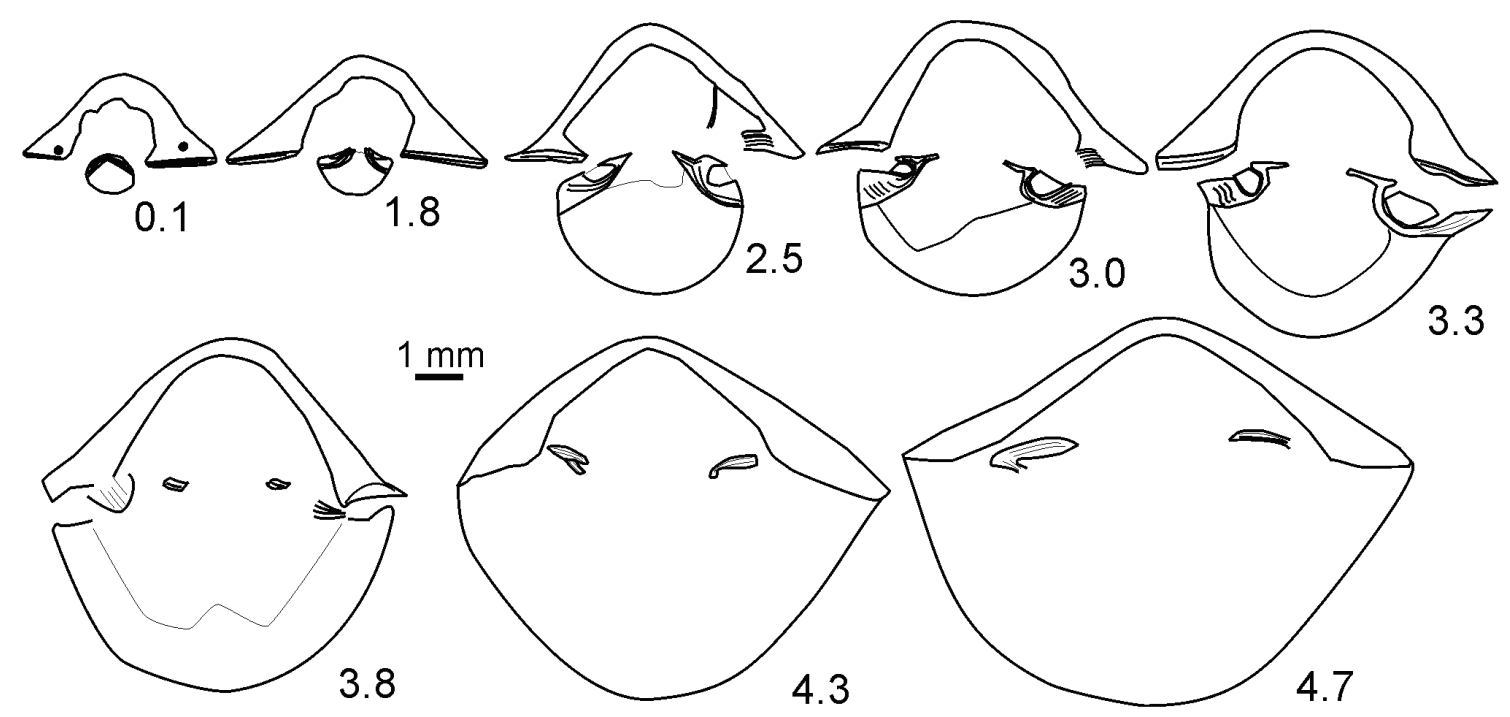

Figure 9. Selected transverse serial sections illustrating the internal structures in Rugosatrypa flexibilis (Cherkesova in T. Modzalevskaya \& Cherkesova, 1994), GM IDPMG 42/201, Lower Devonian, lower Pragian, Heceta Island, Southeast Alaska. Scale bar represents 1 mm; numbers represent distance from initial section through specimen; length of sectioned specimen $18.8 \mathrm{~mm}$.

in common (Blodgett and Baranov, personal observation) with the mapped outcrop of the Devonian age Wadleigh Limestone of the Ham Island group shown on Plate 1 of Eberlein \& Churkin (1970, their Dw unit). This small island was initially collected for fossils (USGS locality 2038-SD) by A.F. Buddington and was cited as being Middle Devonian in age based on identifications by Edwin Kirk (Buddington \& Chapin 1929, p. 105). It is indicated as locality F-43 in Eberlein et al. (1983). Our work indicates an early Pragian age based on the brachiopod fauna (sharing many species with 03RB16) and also by the fact that Savage (1977) reported early Pragian conodonts from here as well. Correlation of the Early Devonian age limestones of northeastern Heceta Island was previously discussed in papers published by Baranov \& Blodgett $(2011,2012)$. It is necessary only to add that the findings here of Dubovikovia cf. kuzmini (Cherkesova) and Rugosatrypa flexibilis (Cherkesova) once again confirming correlation of the Early Devonian limestones of the northeast part of Heceta Island with the Uryumskay, Tolbatskay and basal part of Daksanskay layers (the lower Pragian beds) of Taimyr (Cherkesova 1968) and the early Pragian age Soda Creek Limestone (named by Blodgett et al. 2000) from west-central Alaska.

\section{Conclusions}

The rhynchonellid and atrypid brachiopods described and illustrated here considerably amplify our taxonomic knowledge of such faunal elements from the Pragian of northwestern North America and Southeast Alaska in particular. The brachiopods described here show their closest affinities to coeval brachiopod faunas from the Soda Creek Limestone
(Farewell terrane) of west-central Alaska, Taimyr, and Selennyakh Ridge in Northeast Asia. Most of Alaska is considered to be comprised of allochthonous accreted terranes that are not native to North America. None of the brachiopod species reported from the Pragian on Heceta Island have been reported from North American craton-bound strata in Alaska, the Yukon, or elsewhere in northwestern Canada. Blodgett et al. (2010) considered the Silurian and Devonian fauna of the Alexander and Farewell terranes of southern Alaska to be most similar to those of Siberia.

The fauna described by Savage (1981) from USGS locality 2689-SD is part of the Alexander terrane of Southeast Alaska, and shows strong undoubted biogeographic affinities with the coeval early Pragian Soda Creek Limestone (Blodgett et al. 2000) from west-central Alaska (part of the Farewell terrane), as well as Taimyr, and Selennyakh Ridge. This is clearly indicated by Soda Creek brachiopods that are conspecific or very similar to those described by Savage (1981) from USGS locality 2689-SD as Schizophoria cf. S. fragilis Kozlowski, Mesodouvillina (Protocymostrophia) cf. M. (P.) costatula (Barrande), Nucleospira hecetensis Kirk \& Amsden, and Reticulariopsis sp., which we intend to further investigate in the future.

\section{Acknowledgments}

We wish to express our profound gratitude to A.G. Stepanov from the Institute of Diamond and Precious Metals Geology, Yakutsk Research Center, Siberian Division, Russian Academy of Sciences for photographing the brachiopod specimens. Work was executed in part with financial support of the Russian Fund for Basic Research (grant 13-05-00520) and Program of the Presidium of the Russian Academy of Science No. 23, Project No. 23.1. 
We also wish to gratefully acknowledge the useful reviews of Michal Mergl, Michael Sandy, Peter Isaacson, and Howard Feldman. We thank James F. Baichtal (U.S. Forest Service, Thorne Bay, Alaska) for providing logistical support which made possible the collection of the material described herein.

\section{References}

BARANOV, V.V. 1980. Morphologia crur i novye taksony rinkhonellid [Morphology of crura and new taxa of rhynchonellids]. Paleontologicheskii zhurnal 1980(4), 75-90.

Baranov, V.V. \& BlodgetT, R.B. 2011. Korrelatsia nizhneprazhskikh otlozhenii (nizhnii devon) Alaski i arkticheskikh regionov Vostochnoi Sibiri [Correlation of the Lower Pragian beds (Lower Devonian) in Alaska and the Arctic regions of Eastern Siberia]. Otechestvennya geologia 5, 38-42.

Baranov, V.V. \& Blodgett, R.B. 2012. Problemnye voprosy granits i korrelatsya prazhskogo yarusa (nizhnii devon) okrainnykh morei Angaridy [Problematic questions concerning the boundaries and correlation of the Pragian Stage (Lower Devonian) of the marginal seas of Angarida]. Nauka i obrazovanie 4, 9-13.

Baranov, V.V. \& Schiskina, G.R. 1995. Novye paleozoiskie rinkhonellidy Vostochnoi Yakutii i Dalnego Vostoka [New Paleozoic rhynchonellids of Eastern Yakutia and the Far East]. 44-67. In Slastenov, Y.L. (ed.) Regionalnaia geologia Yakutii (sbornik nauchnykh statei). Izdatelstvo Yakutskogo Gosudarstvennogo Universiteta, Yakutsk.

BARRANDE, J. 1879. Systême silurien du centre de la Bohême. Ière partie. Recherches paléontologiques. Vol. 5. Classe des Mollusques. Ordre des Brachiopodes. 226 pp. Privately published, Prague \& Paris.

Blodgett, R.B., Boucot, A.J., Rohr, D.M. \& Pedder, A.E.H. 2010. The Alexander terrane - A displaced fragment of northeast Russia? Evidence from Silurian-Middle Devonian megafossils and stratigraphy. Memoirs of the Association of Australasian Palaeontologists 39, 325-341.

Blodgett, R.B., Rohr, D.M., Measures, E.A., Savage, N.M., Pedder, A.E.H. \& Chalmers, R.W. 2000. The Soda Creek Limestone, a new upper Lower Devonian formation in the Medfra quadrangle, west-central Alaska, 1-9. In PinNeY, D.S. \& KaUth, P.K. (eds) Short Notes on Alaska Geology 1999: Alaska Division of Geological \& Geophysical Surveys Professional Report 119.

Buddington, A.F. \& Chapin, T. 1929. Geology and mineral deposits of southeastern Alaska. U.S. Geological Survey Bulletin 800, 1-398.

Cherkesova, S.V. 1968. Rhynchonellidy podsemeistva Hebetoechiinae iz nizhnedevonskikh otlozhenii Tsentralnogo Taimyra [Rhynchonellids subfamily Hebetoechiinae from the Devonian strata of Central Taimyr]. Nauchno-issledovatel'skii institut geologii Arktiki (NIIGA), Paleontologiia i biostratigrafiia, Uchenye zapiski 27, 16-45.

Cherkesova, S.V. 1994. Opisanie brachiopod, 38-90. In ModzALEVSKAyA, T.L. \& Cherkesova, S.V. Stratigraphia i fauna nizhnedevonskikh otlozhenii tareiskogo opornogo razreza
(Taimyr) [Stratigraphy and fauna of the lower Devonian beds of the tareiskyi basic section (Taimyr)]. Izdatelstvo Nedra, St. Petersburg.

COOPER, G.A. 1942. New genera of North American brachiopods. Journal of the Washington Academy of Sciences 32(8), 228-235.

Copper, P. \& Racheboeuf, P. 1985. Devonian atrypoid brachiopods from the Armoricain Massif, Northwestern France. Palaeontographica, Abteilung A 187(1-3), 58-104.

Eberlein, G.D. \& Churkin, M., JR. 1970. Paleozoic stratigraphy in the northwest coastal area of Prince of Wales Island, southeastern Alaska. United States Geological Survey Bulletin 1284, 1-67.

Eberlein, G.D., Churkin, M., Jr., Carter, C., Berg, H.C. \& Ovenshine, A.T. 1983. Geology of the Craig Quadrangle, Alaska. United States Geological Survey Bulletin Open-File Report 83-91, 1-52.

GiLL, T. 1871. Arrangements of the Families of Mollusks. Smithsonian Miscellaneous Collections 227, 1-49.

HAVLíčEK, V. 1959. Rhynchonellacea im böhmischen älteren Paläeozoikums (Brachiopoda). Věstník Ústředního ústavu geologického 34(1), 78-82.

HAVLíčEK, V. 1960. Bericht über die Ergebnisse der Revision der böhmischen Altpaläeozoischen Rhynchonelloidea. Věstník Ústředního ústavu geologického 35(3), 241-244.

HAVLíčEK, V. 1961. Rhynchonellacea im böhmischen älteren Paläeozoikums (Brachiopoda). Rozpravy Ústředního ústavu geologického 27, 1-211.

HAVLíčEK, V. 1982. New genera of rhynchonellid and camerellid brachiopods in the Silurian of Bohemia. Věstník Ústředního ústavu geologického 57(6), 365-372.

HavlíčEK, V. 1987. Lower Devonian and Eifelian Atrypacea (Brachiopoda) in Central Bohemia. Sborník geologických věd, Paleontologie 28, 61-115.

HavlíčEK, V. 1992. New Lower Devonian (LochkovianZlichovian) rhynchonellid brachiopods in the Prague Basin. Sborník geologických věd, Paleontologie 32, 55-122.

JIN, J. 1989. Late Ordovician-Early Silurian rhynchonellid brachiopods from Anticosti Island, Quebec. Biostratigraphie $d u$ Paleozoique 10, 1-127.

Kirk, E. \& Amsden, T.W. 1952. Upper Silurian brachiopods from southeastern Alaska. Descriptions and illustrations of a fauna from the Islands of Kosciusko and Heceta. United States Geological Survey Professional Paper 233-C, 53-66.

Kozlowski, R. 1929. Les Brachiopodes gothlandiens de la Podolie Polonaise. Palaeontologia Polonica 1, 1-254.

KuHn, O. 1949. Lehrbuch der Palaeozoologie. 326 pp. E. Schweizerbart'sche Verlagsbuchhandlung, Stuttgart.

ModzalevsKaya, T.L. 1981. Brakhiopody pozdnego silura i rannego devona Pripolyarnogo Urala i gryady Chernysheva [Upper Silurian and Late Devonian brachiopods from the Subpolar Ural and Chernyshev Ridge]. Ezhegodnik Vsesoyuznogo paleontologicheskogo obschestva 24, 173-204.

Nikiforova, O.I. 1954. Stratigrafiia i brakhiopody siluriiskikh otlozhenii Podolii [Stratigraphy and brachiopods of the Silurian deposits of Podolia]. 218 pp. Gosgeoltekhizdat, Moskva.

Oliver, W.A., Merriam, C.W. \& Churkin, M. 1975. Ordovician, Silurian, and Devonian corals of Alaska. United States Geological Survey Professional Paper 823-B, B13-B44. 
Plodowski, G. 1973. Revision der Brachiopoden-Fauna des OberSiluriums der Karnischen Alpen, 2: Rhynchonellacea aus den Zentralkarnischen Alpen. Senckenbergiana lethaea 54(1), 65-103.

RZHONSNITSKaya, M.A. 1956. Systematization of Rhynchonellida, 125-126. In Guzman, E. (ed.) Resumenes de los Trabajos Presentados. Paleontología, Taxonomía y Evolucion: Sección VII. Report 20. Congreso Geologico Internacional, Mexico D.F., Mexico.

RzHONSNitskaya, M.A. 1960. Otryad Atrypida, 257-264. In ORLov, Y.A. (ed.) Osnovy Paleontologii: Mshanki, Brakhiopody [Fundamentals of Paleontology: Bryozoa, Brachiopoda]. Izdatel'stvo Akademii nauk SSSR, Moskva.

RzHONSNITSKAYA, M.A. 1968. Novye vidy srednedevonskikh septalariid i gipotiridiid okrain Kuznetskogo basseina [New species of Middle Devonian septalariids and hypothyridiniids from the margins of the Kuznetsk Basin], 117-122. In MAKRIDIN, B.P. (ed.) Novye vidy drevnikh rastenii $i$ bespozvonochnykh SSSR 2(1). Izdatelstvo Nedra, Moskva.

Rzhonsnitskaya, M.A. 1975. Biostratigrafiia devona okrain Kuznetskogo basseina. Tom 2. Opisanie brakhiopod. Chast 1. Pentamerida i Atrypida [Biostratigraphy of the Devonian in the Margin of the Kuznetsk Basin. Vol. 2: Description of Brachiopods, Pt. 1. Pentamerida and Atrypida]. Vsesoiuznyi Nauchno-issledovatel'skii geologicheskii institut (VSEGEI), Trudy 244, 1-232.

Sartenaer, P. 1961. Etude nouvelle, en deux parties, du genre Camarotoechia Hall and Clarke, 1893. Deuxième partie: Cupularostrum recticostatum n. gen., n. sp. Institut Royal des Sciences Naturelles de Belgique, Bulletin 37(25), 1-15.
SAvage, N.M. 1977. Lower Devonian conodonts from the Karheen Formation, southeastern Alaska. Canadian Journal of Earth Sciences 14, 278-284. DOI 10.1139/e77-029

SAvage, N.M. 1981. A reassessment of the age of some Paleozoic brachiopods from southeastern Alaska. Journal of Paleontology $55(2), 353-369$.

SAvage, N.M. 1996. Classification of Paleozoic rhynchonellids, 249-260. In Cooper, P. \& Jin, J. (eds) Brachiopods. A.A. Balkema, Rotterdam.

SAVAGE, N.M. 2002a. Rhynchotrematoidea, 1047-1091. In KAESLER, R.L. (ed.) Treatise on Invertebrate Paleontology. Part H. Brachiopoda (revised). Volume 4. Geological Society of America \& University of Kansas, Lawrence.

Savage, N.M. 2002b. Camarotoechioidea, 1132-1164. In KAesLer, R.L. (ed.) Treatise on Invertebrate Paleontology. Part H. Brachiopoda (revised). Volume 4. Geological Society of America \& University of Kansas, Lawrence.

Schmidt, H. 1965. Neue Befunde an Paläozoischen Rhynchonellacea (Brachiopoda). Senkenbergiana lethaea 46(1), $1-25$.

Schuchert, C. 1913. Brachiopoda, 355-420. In Von Zittel, K.A. (ed.) Paleontology, $2^{\text {nd }}$ ed., Vol. 1 (Translated by Eastman C.R.). London.

Schuchert, C. \& LeVene, C.M. 1929. New names for brachiopod homonyms. American Journal of Science 5(17), 119-122. DOI 10.2475/ajs.s5-17.98.119

Whitfield, R.P. 1896. Description of a new genus of fossil brachiopod from the Lower Helderberg Limestones. Bulletin of the American Museum of Natural History 8, 231-232. 